\title{
Will Basson come out on top?
}

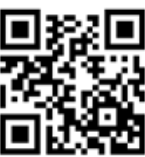

The seasoned legal team of apartheid-era chemical warfare expert and top cardiologist Dr Wouter Basson will within a fortnight ask the Medical and Dental Professions Board (MDPB) committee that found him guilty of violating basic medical ethics to recuse itself entirely.

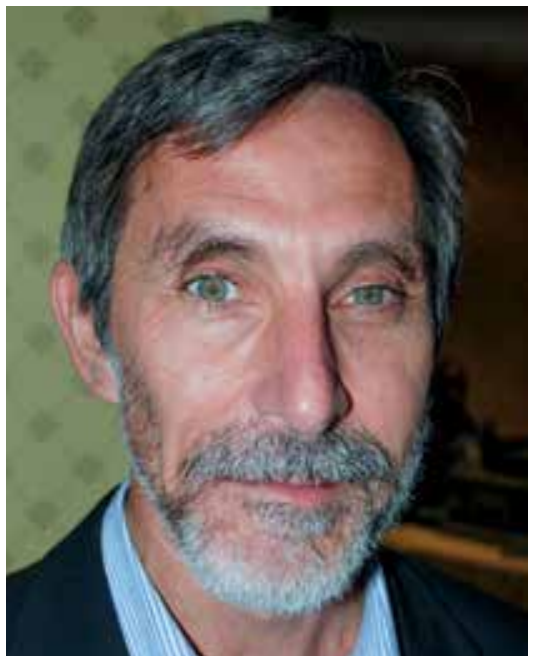

Prof. Jannie Hugo.

This follows their having secured a High Court injunction on 19 January to halt Basson's professional conduct sentencing hearing so they could prepare an application to the committee to recuse itself, claiming that its two members signed or approved of at least one of about 30 petitions calling for Basson to be struck from the medical register of the Health Professions Council of South Africa (HPCSA). The MDPB (one of the many HPCSA boards) committee last year found Basson guilty of unprofessional conduct, saying that he 'defiled the unique and sacred position of doctors' by actively furthering warfare via the production, distribution and use of teargas and drugs against the apartheid regime's enemies some 30 years ago. The HPCSA, charged with 'guiding the professions and protecting the public', has taken 7 years to get to this point, in a roller-coaster ride of legal technicalities and procedural delays. Now there is the possibility that should Jaap Cilliers, SC, the veteran legal counsel of several high-profile right-wing court victories, succeed in getting the committee to reluctantly recuse itself, the entire hearing will have to start from scratch either that, or new committee appointees will have to pick up the hearing where it left off in January (i.e. witnesses testifying in aggravation of sentence, the central theme of which was Basson's demonstrable lack of any remorse for his actions). On 12 and 13 March, Basson's legal team will try to provide compelling evidence to committee chairperson Prof. Jannie Hugo and committee member Prof. Eddie Mhlanga (both advised by retired former Judge President Fritz Eloff) that they signed or approved of any one of the many petitions calling for Basson to be struck from the medical register. The defence team have also argued that Hugo's and Mhlanga's 'conduct' after it asked them whether they were members of any organisation that signed an anti-Basson petition is a telling factor in support of their recusal application. The unspoken threat of yet another Cilliers High Court application will perforce focus the minds of the committee.

In his response to the successful High Court defence application, Hugo admitted that he was a member of the Rural Doctors Association of South Africa and the South African Medical Association, both of which circulated strongly worded petitions calling for Basson to be struck from the medical roll. However, he denied ever signing any petition or taking part in formulating any of them. He said that the reason was simple: 'I could not allow myself to be influenced by and/or participate in processes relevant to the issues to be determined in the proceedings, which were occurring outside the hearings.' Mhlanga did not submit anything to the High Court about membership of any of the organisations that circulated 'anti-Basson' petitions, but Hugo testified that Mhlanga had informed him that his response was identical to his own. Judge A J Bam said that both Hugo and Mhlanga were constitutionally obliged to furnish a proper explanation of their possible involvement and/or knowledge of the petition to Cilliers. Their refusal to do so was not justified, and was irregular. Judge Bam ordered the HPCSA to pay the costs of the application.

\section{Walk-out drama precedes High Court intervention}

The impending recusal move is without precedent in the HPCSA's history of professional conduct hearings, and may well lay bare its often controversial and sometimes dysfunctional processes - at least as much as whether its professional conduct committee conducted itself towards Basson with any historical bias. There was drama during the January hearing when the pro forma complainant (the HPCSA) called a fresh witness in aggravation of sentence. Cilliers stood up and asked that proceedings be adjourned to enable him to prepare a recusal application, explaining why. Hugo refused, saying that proceedings should continue. Cilliers walked out of the hearing in protest, filing his
High Court application. Basson, in testimony prior to his earlier acquittal on multiple charges of murder, fraud and drug dealing in his 2002 criminal trial (which earned the professionally highly regarded Durbanville cardiologist the moniker 'Dr Death'), and the State's subsequent failed appeal bids to the Supreme Court and the Constitutional Court (ending in 2005), has insisted that his conduct came within the context of war and conflict and that no proof was ever obtained that he caused harm or death. However, the professional conduct committee found that the ethical values of beneficence, non-malificence, justice and autonomy' had not changed since the time of his ethical offences, and that medical ethics were especially important in times of war and conflict. Hugo found that Basson had contravened both the Geneva Declaration of 1948 and the UN convention on the prohibition of and stockpiling of dangerous weapons. No doctor could claim ignorance of their expected professional behaviour, he added.

Basson, while project officer of the 1980s and early 1990s secret 'Project Coast' and its military front teargas and drugs manufacturing company Delta G, co-ordinated the largescale production and stockpiling of Mandrax, ecstasy and teargas and provided 'disorientating substances for cross-border kidnapping. $\mathrm{He}$ also supplied cyanide suicide capsules to apartheid undercover operatives for use when captured - something the committee heard caused an agonising death, not the quick and painless demise of spy novels.

\section{Cilliers' colourful court career}

Cilliers, regarded as one of the more able senior counsels by his peers, took on the so-called 'generals case' in the mid-1990s when former defence minister Magnus Malan and 20 senior military officers stood trial for murdering 13 people, some of them children, in the KwaMakhutha township massacre of 1987. All were acquitted in a 1996 ruling that polarised black and white South Africa. Besides getting Basson acquitted of the criminal charges, Cilliers less successfully took on the case of Jewell Crossberg, the Limpopo farmer given a 20-year sentence for shooting dead a Zimbabwean farmworker, and that of the 'Waterkloof Four', young Pretoria men sentenced to 12 years for 'cruelly' murdering and assaulting a homeless black man.

\section{Chris Bateman}

chrisb@hmpg.co.za

S Afr Med J 2015;105(3):168.

DOI:10.7196/SAMJ.9463 